\title{
An amalgamation of 3D city models in urban air quality modelling for improving visual impact analysis
}

\author{
U. Ujang ${ }^{1}$, F. Anton ${ }^{2}$, A. Ariffin ${ }^{1}$, D. Mioc $^{2} \&$ S. Azri ${ }^{1}$ \\ ${ }^{I}$ Department of Geoinformation, Faculty of Geoinformation \\ and Real Estate, Universiti Teknologi Malaysia, Malaysia \\ ${ }^{2}$ Department of Geodesy, National Space Institute, \\ Technical University of Denmark, Denmark
}

\begin{abstract}
Geographical Information Systems (GISs) can be seen as a common tool to map and visualize the air quality index based on geographical locations. However, in urban areas, the area resolution for air quality models is less than 2 kilometres. Since the main emissions agent in urban areas is predominantly vehicular engines, the situation will become worse when pollutants are trapped between buildings and disperse inside the street canyon and move vertically to create a recirculation vortex. Studying and visualizing the recirculation zone in 3D visualization is conceivable by using 3D city models as physical data input. The Level of Details (LoD) in 3D city models (i.e. LoD1 and LoD2) ascertains the potentials of implementing air quality modelling for urban areas. Therefore, this research is focused towards investigating the integration of 3D city models in air quality modelling for urban areas. The results presented show the simplicity of using 3D city models as a physical data input in air quality modelling and the 3D air quality will improve insight for visual impact analysis (i.e. analysing the immersion of a recirculation zone). The results are advantageous for city planners, architects, engineers and policy makers to design the street geometry (building height and width, green areas, pedestrian walks, roads width, etc.).

Keywords: urban air pollution, GIS and 3D city model.
\end{abstract}




\section{Introduction}

Air quality indexes (AQI) value mapping using Geographical Information System (GIS) can be seen as an advantageous instrument to be incorporated for better exemplification of air pollution circumstances in a geographical location. Visualization of two-dimensional (2D) map illustrates the physical boundary of AQI values for specific location. In the other hand, researchers developed tools and extensions to assimilate the air quality modelling with GIS as the visualization package. This is because the spatial analysis and in this situation the visual impact gives a better insight for end-users.

In this research, the main focus is on the urban areas. To describe, it involves with high density of population, buildings, traffic volumes and smaller region resolution (area). To evaluate air quality in urban area requires a different approach from conventional air quality modelling. Usually air quality monitoring stations are located at airports or any meteorological stations which is not located in urban areas. However in urban area, air quality values can be different from one street to another since it corresponds to the amount of traffic volume.

An AQI reading at any air quality monitoring station located outside urban area will not reflect the exact value of air quality inside an urban area. The scale resolution for urban area is less than $2 \mathrm{~km}$ meanwhile air quality monitoring stations covers larger scale than $2 \mathrm{~km}$. therefore in the next section, discussion are focused to the urban air quality modelling which will highlight the issues, approach and suitable approach for acquiring the AQI value in urban area. Later the usage of 3D city model can be used as a physical (spatial) data in urban air quality modelling for better representation of AQI values in 3D environment.

\section{Urban air quality modelling: the importance and bounds}

Urban air quality modelling requires more monitoring stations to be positioned near to cities whereby it is unmanageable and not practical. Due to that limitation, monitoring stations are planned for large scale air quality model (Roberts [1] and Ferradás et al. [2]). In urban area, major pollution agent is contributed by vehicle (land transportation) emission. This fact is supported by other researchers (Fu et al. [3]) in identifying the major source of air pollution in major cities. This moving emission source will create a line of emission along the roadway. Therefore this emission source can be categorized as a link-based emission source. A link-based of $\mathrm{CO}$ emission from land transportation will disperse along the roadway between buildings inside the street geometry.

However to model the dispersion along the roadway will require high scale resolution information. Scale model in air quality modelling can be characterized into several groups. According to Srivastava and Rao [4] the categories are Global, Synoptic, Regional, Meso-scale and Micro-scale model. Different scale model gives difference influence in air quality modelling visualization. Table 1 shows the different domain scale for each category. Each domain identifies different 
accuracy of air quality monitoring. Smaller grids will give a more accurate model for specific area compared to larger grids whereby it will calculate the mean for total grids.

Table 1: Typical domain for different scale model (Srivastava and Rao [4]).

\begin{tabular}{|c|c|c|c|}
\hline Model & Typical domain scale & $\begin{array}{c}\text { Typical } \\
\text { resolution }\end{array}$ & Motion example \\
\hline Macro-scale & $200 \times 200 \times 100 \mathrm{~m}$ & $5 \mathrm{~m}$ & $\begin{array}{c}\text { Molecular diffusion, } \\
\text { molecular viscosity }\end{array}$ \\
\hline $\begin{array}{c}\text { Meso-scale } \\
\text { (urban) }\end{array}$ & $100 \times 100 \times 5 \mathrm{~km}$ & $2 \mathrm{~km}$ & $\begin{array}{c}\text { Small plumes, car exhaust, } \\
\text { cumulus clouds }\end{array}$ \\
\hline Regional & $1000 \times 1000 \times 10 \mathrm{~km}$ & $36 \mathrm{~km}$ & $\begin{array}{c}\text { Gravity waves, thunderstorm, } \\
\text { tornados, cloud clusters }\end{array}$ \\
\hline $\begin{array}{c}\text { Synoptic } \\
\text { (continental) }\end{array}$ & $3000 \times 3000 \times 20 \mathrm{~km}$ & $80 \mathrm{~km}$ & $\begin{array}{c}\text { Weathers fronts, tropical } \\
\text { storms, hurricanes, Antarctic } \\
\text { ozone hole }\end{array}$ \\
\hline Global & $65000 \times 65000 \times 20 \mathrm{~km}$ & $4^{\circ} \times 5^{\circ}$ & $\begin{array}{c}\text { Global wind speed, Rossby } \\
\text { (planetary) waves, global } \\
\text { warming }\end{array}$ \\
\hline
\end{tabular}

Nevertheless, current situations in many countries the available information are range from Global to Regional scale model. It is due to several factors. Vardoulakis et al. [5] discovered that monitoring stations in urban areas are limited to a few sites and often it is located at airports. As for an example, the Malaysian Meteorological Department monitors 22 air pollution monitoring stations throughout the country. Meanwhile, Department of Environment Malaysia only has 15 continuous air quality monitoring stations in urban areas and their major focus is in Klang Valley whereby the capital city of Malaysia, Kuala Lumpur is located. These stations are based on regional scale model and did not focus on a specific area that less than $2 \mathrm{~km}$ grid. Unfortunately, the major source of air pollution in urban cities comes from vehicle emissions. Heavy traffic and slow vehicle movements seem will trap the pollutant emission inside of the urban geometry. The circulation of pollutant between buildings will worsen if there is no natural ventilation or slow background wind speed. However, it is crucial to monitor air pollution in urban cities in order to have a better and healthy living standard. But to deploy monitoring stations at street level will affect the cost. This is one of the reasons why it is difficult to have a micro-scale model for air pollution monitoring in urban areas (Steed et al. [6]).

Another alternative is to perform air quality modelling in the urban area (Woo et al. [7] and Elbir et al. [8]). Since the agent (pollutants) is a moving object, appropriate modelling approach in a rapid development place need to be deliberate comprehensively. In a practical approach, the urban air quality model requires several data input (Vardoulakis et al. [5]). The geometry of an area model is important in order to produce a more accurate result. To date, there are complications in data acquisition for rapid development places. New data input like building geometries (e.g. building's height, width and gaps) need to be 
collected from ground measurements and re-calculated with other inputs (e.g. street geometries). This data is important in air quality modelling (dispersion model) to produce an accurate output.

In air dispersion models, it consists of two major groups of data: meteorological and physical data (Figure 1). Meteorological department monitors information regarding to meteorological circumstances (i.e. wind speed, pollution concentration, wind direction and etc.). Moreover, in several countries these data are available for public use. On the other hand for physical (spatial) data, the exact geometrical state for the modelling is required because different geometries for the street canyon will affect the dispersion movement. Therefore, the exact street geometry measurements are necessary in order to calculate the air dispersion model.
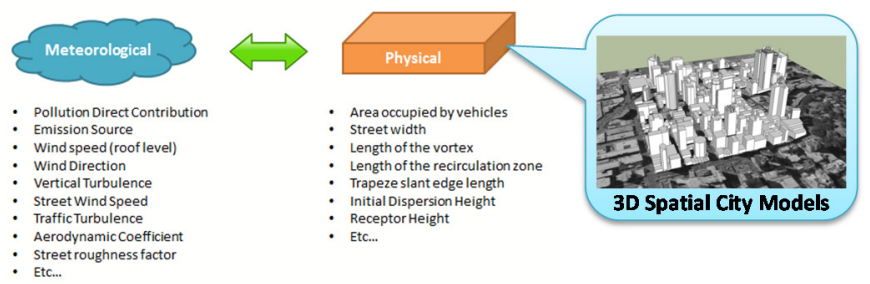

Figure 1: Urban air dispersion modelling and 3D spatial city model conceptual data integration.

Current practice in acquiring those data is via ground or space measurement inspection such as field survey, photogrammetry, laser scanning, remote sensing or using architectural/floor plans (Tack et al. [9], Haala and Kada [10] and Zalama et al. [11]). But in order to measure the geometrical data for developing areas, there are complications in terms of data acquisition. Development area such as in major cities will involves with rapid changes that causes data updating difficulties for air pollution modelling. Therefore this research proposed a unified data model between air quality models with 3D spatial city modelling. As in Figure 1, all spatial information needed in air quality models is available in 3D spatial city modelling. Although 3D spatial city model (i.e. CityGML) is an open-standard data model, nevertheless with a proper amalgamation with air quality modelling, 3D spatial city model can be a new way of data input for visualizing air pollution dispersion model.

\section{3D city modelling}

The trends of 3D city modelling development can be seen from the efforts of many (Izham et al. [12], Over et al. [13], Uznir et al. [14] and Toshev et al. [15]). Some of them are coming from a private business, government, academicians, researchers or group of students. There are various tools on the market which facilitate these parties to develop those 3D models. Some of them develop this model as a hobby while others develop it as a planning for the future. However, 
these models are mainly used for visualization. Most of the visualization is just to perceive the development that took place in a city or just to get an insight at interesting architectural shapes of buildings with simple information inquiries.

Based on this trend, 3D data will be an important resource in the near future. $3 \mathrm{D}$ visualization gives a better understanding of air pollution dispersion models. In Figure 2, a warning line for $\mathrm{NO}_{2}$ pollution level is drawn on a $3 \mathrm{D}$ building model. Until recently, Metral et al. [17] discovered the integration of air quality models with $3 \mathrm{D}$ city model can create an interoperable way for air quality models in 3D. The existing CityGML structure consists of useful information for the ontology of the urban planning process (OUPP).

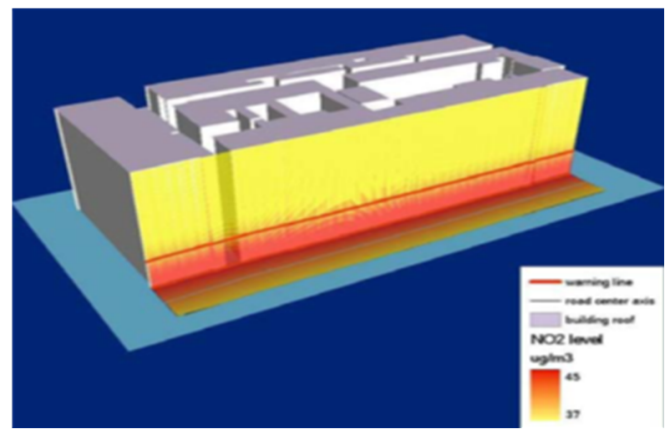

Figure 2: Pollution warning line (Wang et al. [16]).

The relevancy of using the 3D spatial city model (CityGML) for air quality monitoring is its scale. As discussed in previous section, urban air quality modelling requires a scale model that is less than $2 \mathrm{~km}$ resolution. But to acquire data for micro-scale urban areas is a challenging task. Detailed geometries for buildings and street objects are necessary before executing the calculations. However, in CityGML they have different scales for implementations called the Levels of Detail (LOD). Each five LODs are based on precisely in what way specific model required in different applications (Figure 3). Based on these LODs, LOD1 and LOD2 appear related to the scale model by less than $2 \mathrm{~km}$ resolution in urban air pollution dispersion model. LOD1 is the well-known blocks model comprising prismatic buildings with flat roofs. Meanwhile, a building in LOD2 has differentiated roof structures and thematically differentiated surfaces. The generalizations of spatial objects for each LOD are described in Table 2.

\section{Urban air quality modelling via 3D city modelling}

CityGML consists of modules for different city objects. Among those modules are Building module, City Furniture module and Transportation module where by those modules is important as a physical data input for urban air pollution dispersion modelling (Table 3). Meanwhile other modules such as the Textured Surface module will enhance the $3 \mathrm{D}$ visualization for perceiving the dispersion 


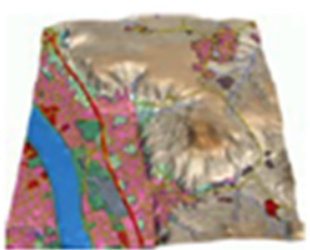

LOD0

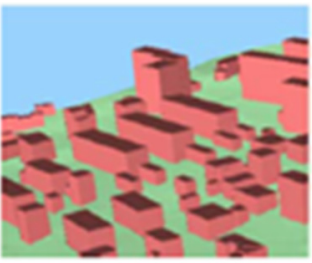

LOD1

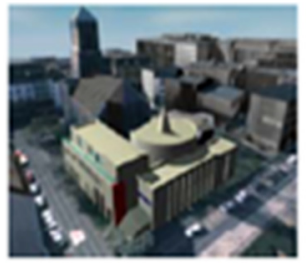

LOD2

LOD3
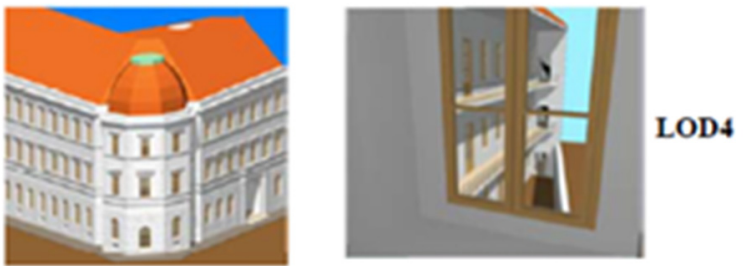

Figure 3: The five levels of detail (LOD) defined by CityGML (Gröger et al. [18]).

Table 2: LOD 0-4 of CityGML with its accuracy requirements (Gröger et al. [19]).

\begin{tabular}{|c|c|c|c|c|c|}
\hline & LOD0 & LOD1 & LOD2 & LOD3 & LOD4 \\
\hline $\begin{array}{l}\text { Model scale } \\
\text { description }\end{array}$ & $\begin{array}{l}\text { regional, } \\
\text { landscape }\end{array}$ & city, region & $\begin{array}{l}\text { city districts, } \\
\text { projects }\end{array}$ & $\begin{array}{c}\text { architectural } \\
\text { models (outside) } \\
\text { landmark }\end{array}$ & \begin{tabular}{|l|} 
architectural \\
models \\
(interior)
\end{tabular} \\
\hline $\begin{array}{l}\text { Class of } \\
\text { accuracy }\end{array}$ & lowest & low & middle & high & very high \\
\hline $\begin{array}{l}\text { Absolute 3D } \\
\text { point accuracy } \\
\text { (position } \\
\text { /height) } \\
\end{array}$ & $\begin{array}{l}\text { lower than } \\
\text { LOD1 }\end{array}$ & $5 / 5 \mathrm{~m}$ & $2 / 2 \mathrm{~m}$ & $0.5 / 0.5 \mathrm{~m}$ & $0.2 / 0.2 \mathrm{~m}$ \\
\hline Generalisation & $\begin{array}{l}\text { maximal } \\
\text { generalisation } \\
\text { (classification of } \\
\text { land use) }\end{array}$ & $\begin{array}{c}\text { object blocks as } \\
\text { generalised } \\
\text { features; > } \\
6^{*} 6 \mathrm{~m} / 3 \mathrm{~m}\end{array}$ & $\begin{array}{l}\text { objects as } \\
\text { generalised } \\
\text { features; }> \\
4 * 4 \mathrm{~m} / 2 \mathrm{~m}\end{array}$ & $\begin{array}{l}\text { object as real } \\
\text { features; }> \\
2 * 2 \mathrm{~m} / 1 \mathrm{~m}\end{array}$ & $\begin{array}{c}\text { constructive } \\
\text { elements } \\
\text { and } \\
\text { openings are } \\
\text { represented }\end{array}$ \\
\hline $\begin{array}{l}\text { Building } \\
\text { installations }\end{array}$ & - & - & - & $\begin{array}{l}\text { representative } \\
\text { exterior effects }\end{array}$ & $\begin{array}{l}\text { real object } \\
\text { form }\end{array}$ \\
\hline $\begin{array}{l}\text { Roof } \\
\text { form/structure }\end{array}$ & no & flat & $\begin{array}{c}\text { roof type and } \\
\text { orientation }\end{array}$ & real object form & $\begin{array}{l}\text { real object } \\
\text { form }\end{array}$ \\
\hline $\begin{array}{l}\text { Roof } \\
\text { overhanging } \\
\text { parts }\end{array}$ & - & - & n.a. & n.a. & Yes \\
\hline City furniture & - & $\begin{array}{l}\text { important } \\
\text { objects }\end{array}$ & prototypes & real object form & $\begin{array}{l}\text { real object } \\
\text { form }\end{array}$ \\
\hline $\begin{array}{l}\text { Solitary } \\
\text { vegetation } \\
\text { object }\end{array}$ & - & $\begin{array}{l}\text { important } \\
\text { objects }\end{array}$ & $\begin{array}{l}\text { prototypes, } \\
\text { higher } 6 \mathrm{~m}\end{array}$ & $\begin{array}{c}\text { prototypes, higher } \\
2 \mathrm{~m}\end{array}$ & \begin{tabular}{|c|}
$\begin{array}{c}\text { prototypes, } \\
\text { real object } \\
\text { form }\end{array}$ \\
\end{tabular} \\
\hline Plant cover & - & $>50 * 50 \mathrm{~m}$ & $>5 * 5 \mathrm{~m}$ & $<$ LOD2 & $<$ LOD2 \\
\hline
\end{tabular}


process and create a more realistic urban environment for visual analysis. From the discussion, it shows that by having a 3D spatial city model like CityGML, there are potentials in incorporating it with air quality monitoring. With the available sources, format, standard, and modules in CityGML, it will provide a reliable platform for air quality monitoring in the 3D spatial city model.

A Unified Modelling Language (UML) integrated data model of air pollution dispersion model with a 3D city model as in Figure 4 is used. UML is a

Table 3: Overview of CityGML's core and thematic extension module.

\begin{tabular}{|c|c|c|c|}
\hline Module & Building & City Furniture & Transportation \\
\hline $\begin{array}{l}\text { XML Namespace } \\
\text { Identifier }\end{array}$ & $\begin{array}{l}\text { http://www.opengis.net } \\
\text { /citygml/building/1.0 }\end{array}$ & $\begin{array}{l}\text { http://www.opengis.net/ } \\
\text { citygml/cityfurniture/1.0 }\end{array}$ & $\begin{array}{l}\text { http://www.opengis.net/ } \\
\text { citygml/transportation/1.0 }\end{array}$ \\
\hline XML Schema File & building.xsd & cityFurniture.xsd & Transportation.xsd \\
\hline $\begin{array}{c}\text { Recommended } \\
\text { Namespace Prefix }\end{array}$ & bldg & frn & $\operatorname{tran}$ \\
\hline $\begin{array}{l}\text { Module } \\
\text { description }\end{array}$ & $\begin{array}{l}\text { Representation of } \\
\text { thematic and spatial } \\
\text { aspects of buildings, } \\
\text { building parts, building } \\
\text { installations, and interior } \\
\text { building structures in } \\
\text { four levels of detail } \\
\text { (LOD 1-4). }\end{array}$ & $\begin{array}{c}\text { Represent city furniture } \\
\text { objects in cities. City } \\
\text { furniture objects are } \\
\text { immovable objects like } \\
\text { lanterns, traffic signs, } \\
\text { advertising columns, } \\
\text { benches, or bus stops that } \\
\text { can be found in traffic } \\
\text { areas, residential areas, } \\
\text { on squares, or in built-up } \\
\text { areas. }\end{array}$ & $\begin{array}{c}\text { Represent the } \\
\text { transportation features } \\
\text { within a city, for example } \\
\text { roads, tracks, railways, or } \\
\text { squares. Transportation } \\
\text { features may be represented } \\
\text { as a linear network or by } \\
\text { geometrically describing } \\
\text { their 3D surfaces. }\end{array}$ \\
\hline
\end{tabular}

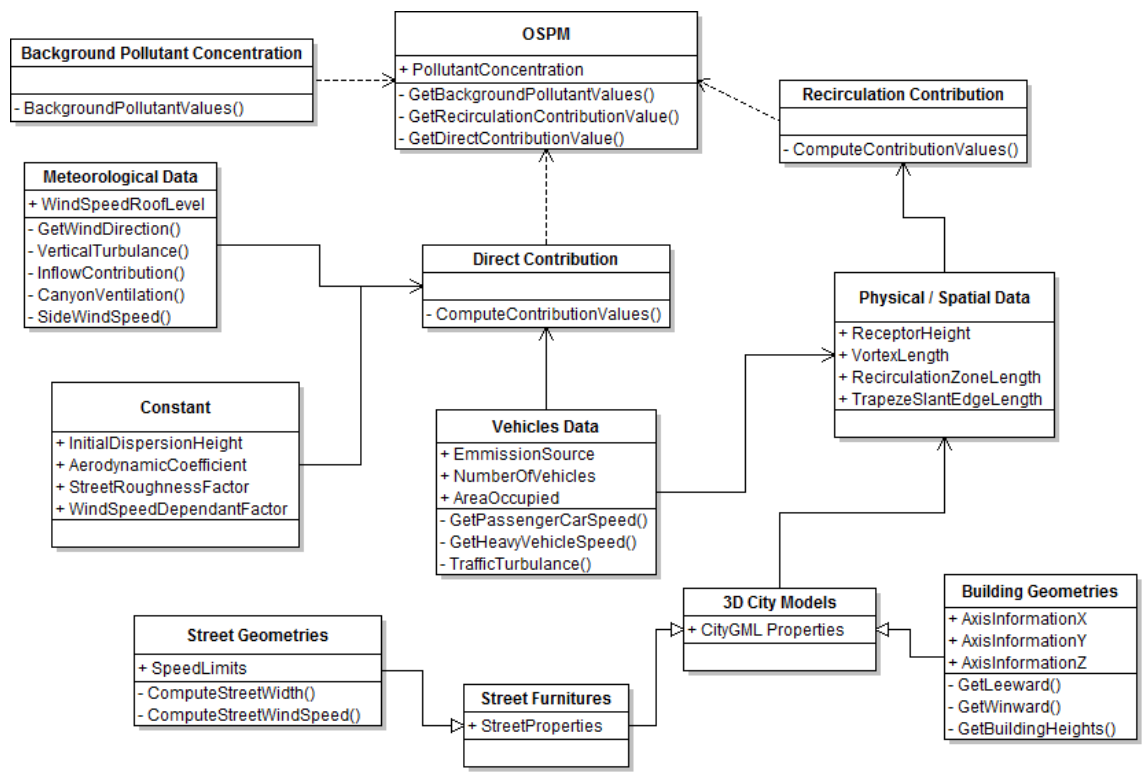

Figure 4: The Unified Modelling Language (UML) for air dispersion model with 3D city model integration. 
standardized general-purpose modelling language in the field of object-oriented software engineering. It shows the attributes of CityGML in conjunction with urban air quality modelling parameters for the amalgamation. The 3D city model encompasses geometrical information which is useful in air pollution dispersion model. One of the advantages of implementing urban air quality modelling in the $3 \mathrm{D}$ city model is the $3 \mathrm{D}$ visualization. For an instance, recirculation zone (Figure 5) is one of the important criteria in the modelling.

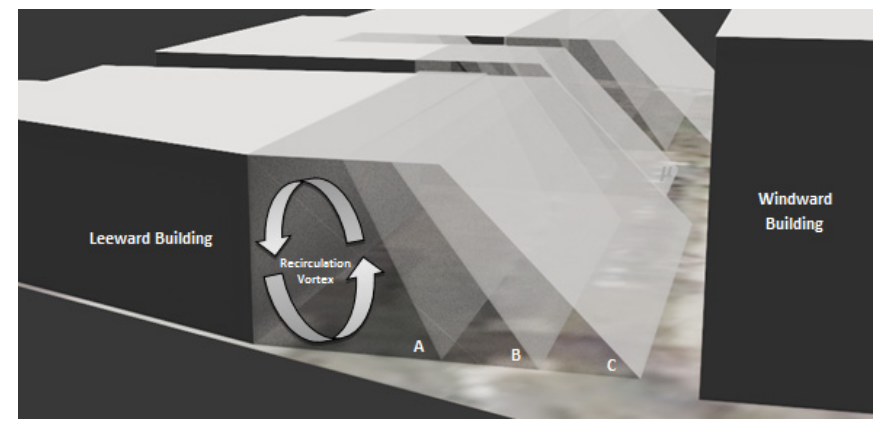

Figure 5: Recirculation zone in the 3D spatial city model with different roof wind speed: (A) $1.0 \mathrm{mph},(\mathrm{B}) 1.5 \mathrm{mph}$ and (C) $2.0 \mathrm{mph}$.

Recirculation zone is a zone where the emissions from vehicular engines are trapped in the zone and mixed with the background pollution that originates from the surrounding area. This situation will get worse when the emissions recirculate inside this zone, creating an increasing air pollution value. The recirculation zone assembles a shape of a trapezoidal prism by a shared boundary with the leeward building. The geometrical characteristics of this trapezoidal prism such as the width of the recirculation zone will mostly depend on the roof wind speed and the height of the leeward building.

The calculation involved in the modelling gives a numerical output for the recirculation zone length. Unfortunately, numerical value is hard to perceive for visual analysis. Moreover, the different roof wind speed will give different values and can affect the canyon geometry. Figure 5 shows the integration of calculating the recirculation zone in 3D spatial city model visualization with 3 different values for roof wind speed. By taking the roof wind speed data, the affected area in the recirculation zone can be calculated, viewed in $3 \mathrm{D}$ and analysed for future references.

\section{Visual development and analysis}

In the urban air quality modelling (dispersion model), the total contribution (C) for a particular street can be apparent at a certain height from the street level. For an example, the computation of physical (3D city model) data input with the meteorological and traffic data input will compute the total contribution (C) at a 
given height. Usually, the attention is given at 1-2 meter above from the street level. However, the impact of the emission recirculation can be seen through to the top of the recirculation zone.

The total contribution (C) can be visualized in the cross section of the trapezoidal prism. The trapezoidal prism can be divided horizontally by having several sections or layers that indicate the total contribution (C) values at a certain height. From the observation, the layer's value is high at the bottom of the trapezoidal prism and it is decreasing when the height rises. From this, the values obtained from the computation can be perceived visually in cross section visualization (Figure 6) which is not capable of displaying it in in 2D or 2.5D GIS framework. The use of 3D city model used in this research is not merely function as the physical data input for the computations, but it provides a better visualization in 3D for better insight of the scenarios. The visualization of the urban air quality modelling integrated with 3D city model is shown in Figure 7.

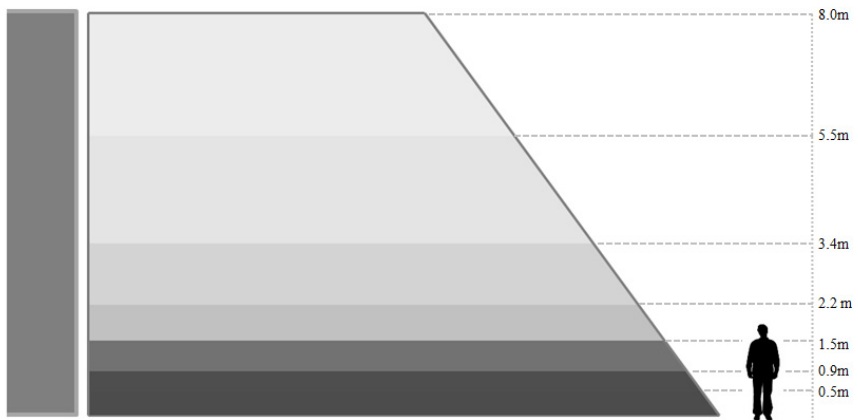

Figure 6: Cross section illustration of the recirculation zone.
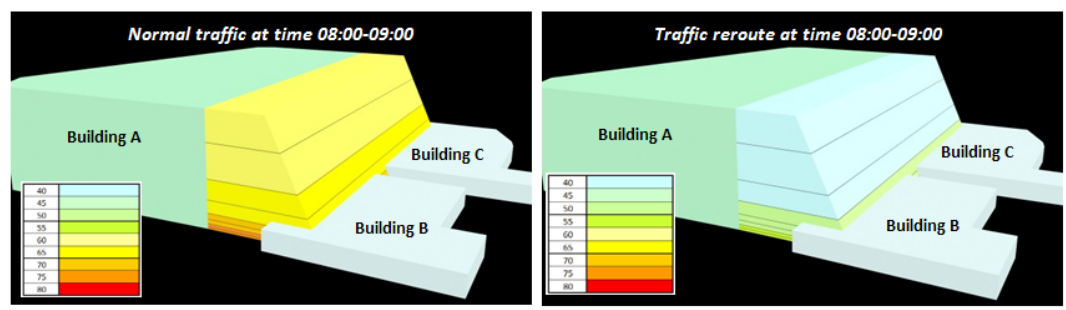

Figure 7: Traffic reroute for heavy vehicle at peak hours.

In the other hand, the value of AQI at street level is subject to the traffic volumes for specific time. Usually during the peak hours, the traffic volume is normally high and it will reflect the air quality of the surrounding area.

As an initiative that can be taken into considerations in increasing the air quality in urban area is to plan for traffic rerouting for vehicles that gives a greater impact to the emissions contributions. Usually in major cities planning, heavy vehicles 
will be reroute to another street with less traffic volumes and in the same time it is accessible to the public. This will improve the traffic flow and in the same time it will increase the air quality for the street. In this research, it can be visualize at the planning stage in order to perceive the surrounding air quality before and after the implementation. The comparison shown in Figure 7 identifies the impact of the planning for designing and structuring the traffic flow in an urban transportation system.

\section{Conclusion}

Data acquisition for urban air pollution dispersion model is at ease by having a unified data model by assimilating urban air quality model with a 3D city model. Visualization in 3D will improve the visual analysis for understanding the behaviour of air pollutant dispersion at street level. This research has demonstrated the applicability of implementing 3D city model in urban air quality modelling. It would be beneficial for city planners, architects, engineers and policy makers to design the street geometry (buildings height and width, green areas, pedestrian walks, roads width, street infrastructures, etc.) in order to improve the natural ventilation and the air quality of the street canyon. In the same time it will improve the life quality of people who lived in crowded cities. This effort will contribute in the direction of sustainable urban development.

\section{References}

[1] Roberts, E. M. Design methodology for optimum dosage air monitoring site selection. Atmospheric Environment (1967), 18, (6, 1984), 1243-1244.

[2] Ferradás, E. G., Miñarro, M. D., Morales Terrés, I. M. and Marzal Martínez, F. J. An approach for determining air pollution monitoring sites. Atmospheric Environment, 44, 21-22, 7(7, 2010), 2640-2645.

[3] Fu, L., Hao, J., He, D., He, K. and Li, P. Assessment of Vehicular Pollution in China. Journal of the Air \& Waste Management Association, 51, 5 (2001/05/01 2001), 658-668.

[4] Anjali Srivastava and Rao, B. P. S. Urban Air Pollution Modeling, Air Quality-Models and Applications. InTech, City, 2011.

[5] Vardoulakis, S., Fisher, B. E. A., Pericleous, K. and Gonzalez-Flesca, N. Modelling air quality in street canyons: a review. Atmospheric Environment, 37, 2 2003), 155-182.

[6] Anthony Steed, Salvatore Spinello, Ben Croxford and Greenhalgh, C. eScience in the Streets: Urban Pollution Monitoring. City, 2003.

[7] Woo, J.-H., Kim, H., Lim, S., Kim, J.-J., Lee, J., Ryoo, R. and Kim, H. AirScope: A Micro-scale Urban Air Quality Management System. Springer Berlin Heidelberg, City, 2010.

[8] Elbir, T., Mangir, N., Kara, M., Simsir, S., Eren, T. and Ozdemir, S. Development of a GIS-based decision support system for urban air quality management in the city of Istanbul. Atmospheric Environment, 44, 4 (2, 2010), 441-454. 
[9] Tack, F., Buyuksalih, G. and Goossens, R. 3D building reconstruction based on given ground plan information and surface models extracted from spaceborne imagery. ISPRS Journal of Photogrammetry and Remote Sensing, 67, 0 (1, 2012), 52-64.

[10] Haala, N. and Kada, M. An update on automatic 3D building reconstruction. ISPRS Journal of Photogrammetry and Remote Sensing, 65, 6 (11, 2010), 570-580.

[11] Zalama, E., Gómez-García-Bermejo, J., Llamas, J. and Medina, R. An Effective Texture Mapping Approach for 3D Models Obtained from Laser Scanner Data to Building Documentation. Computer-Aided Civil and Infrastructure Engineering, 26, 5 (2011), 381-392.

[12] Izham, M. Y., Uznir, U., Alias, A. R., Ayob, K. and Wan Ruslan, I. Influence of georeference for saturated excess overland flow modelling using 3D volumetric soft geo-objects. Computers \& Geosciences, 37, 4 (4, 2011), 598-609.

[13] Over, M., Schilling, A., Neubauer, S. and Zipf, A. Generating web-based 3D City Models from OpenStreetMap: The current situation in Germany. Computers, Environment and Urban Systems 2010).

[14] Uznir, U., François, A., Suhaibah, A., Alias, A. R. and Darka, M. Improving 3D Spatial Queries Search: Newfangled Technique of Space Filling Curves in 3D City Modeling. ISPRS Ann. Photogramm. Remote Sens. Spatial Inf. Sci., II-2/W12013), 319-327.

[15] Toshev, A., Mordohai, P. and Taskar, B. Detecting and parsing architecture at city scale from range data. City, 2010.

[16] Wang, G., Bosch, F. H. M. V. D. and Kuffer, M. Modeling urban traffic air pollution dispersion. City, 2008.

[17] Metral, C., Falquet, G. and Karatzas, K. Ontologies for the Integration of Air Quality Models and 3D City Models. In Proceedings of the Ontologies for Urban Development: Conceptual Models for Practitioners.

[18] Gröger, G., Kolbe, T. H., Czerwinski, A., Nagel, C. Candidate OpenGIS ${ }^{\circledR}$ CityGML Implementation Specification (City Geography Markup Language) Copyright (C) 2006 Open Geospatial Consortium, Inc. All Rights Reserved. Open Geospatial Consortium Inc., City, 2006.

[19] Gröger, G., Kolbe, T. H., Czerwinski, A., Nagel, C. OpenGIS ${ }^{\circledR}$ City Geography Markup Language (CityGML) Encoding Standard. Open Geospatial Consortium Inc., City, 2008. 